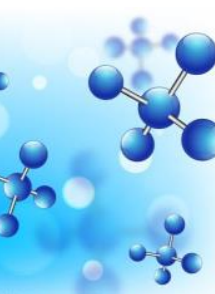

\title{
Relationship of Ferritin Levels of Pregnant Women Who Had Fe Deficiency Anemia with Ferritin Levels andAPGAR of the Neonates
}

\author{
Zuliyana $^{1}$, Yanwirasti ${ }^{2}$, Roza Sri Yanti ${ }^{3}$ \\ ${ }^{I}$ Master of Midwifery, Faculty of Medicine, Andalas University, Padang \\ ${ }^{2}$ Subdivision Anatomy Pathology Faculty of Medicine, Andalas University, Padang \\ ${ }^{3}$ Subdivision Midwifery, Faculty of Medicine, Andalas University / Hospital Dr.M.Djamil Padang
}

\begin{tabular}{l}
\hline TRACK SUBMISSION \\
\hline Recieved: \\
Final Revision: \\
Available Online: \\
KEYWORDS \\
\hline Anemia, Ferritin, APGAR \\
CORRESPONDENCE \\
\hline
\end{tabular}

Phone: 085278236023

E-mail: ulli_uul@yahoo.co.id

\begin{abstract}
Iron deficiency anemia in pregnant women can have a negative impact on the baby, such as placental development, low birth weight, prematurity, baby health, hypoxia, decreased immune status, possibility of having physiological disorders and infant growth. The aim of this study was to determine the relationship of ferritin levels of pregnant women who had Fe deficiency anemia with ferritin levels and Apgarof the neonates. This was a cross sectional study in the population of pregnant women who had Fe deficiency anemia and neonates who met the inclusion criteria taken by consecutive sampling technique in the working area of Lubuk Buaya Health Center, Ambacang Health Center and Ikur Koto Health Center. Examination of ferritin levels was carried out in the Biomedical Laboratory of Faculty of Medicine, Andalas University using ELISA method. Data were analyzed by Pearson Test and Mann-Whitney Test. The results of this study showed there was no significant relationship between maternal ferritin levels on neonatal ferritin $r=0.248$, $p$ $=0.204$. It also showed that there was no relationship between maternal ferritin levels on APGAR $\mathrm{p}$ value $=0.199$ and there was a significant relationship between neonatal ferritin levels on APGAR $p$ value $=0.002$. The conclusion of this study is that there was a positive relationship between maternal ferritin levels with neonatal ferritin levels, there was no significant relationship between maternal ferritin levels and APGAR score, there is a significant relationship betweenneonatal ferritin levels with APGAR score. By improving nutrition, socioeconomic, qualitative antenatal care, early referral of risky cases and iron supplementation can reduce the incidence of anemia.
\end{abstract}




\section{INTRODUCTION}

Iron deficiency anemia is a public health problem that can cause morbidity and mortality. The prevalence of iron deficiency anemia attacks in almost all age. One is pregnant women. Iron deficiency anemia in pregnant women can have a negative impact on the baby, such as placental development, low birth weight, prematurity, infant health, hypoxia, decreased immune status, possible physiological disorders and infant growth and development. ${ }^{1}$

Anemia Fe deficiency in pregnant women is still a problem in the health sector, because the prevalence is still high, namely the prevalence of anemia there are $48 \%$ of pregnant women from total anemia as much as $56 \%$. Besides that the anemia suffered by pregnant women has a bad effect on the baby. The cause of anemia is clearly not yet known whether the cause of anemia is due to iron deficiency, parasitic infection, vitamin A, folate deficiency, Vitamin B12 or because of nutrition. However, iron deficiency is a major cause of anemia in the world. ${ }^{2}$

Maternal risk of iron deficiency anemia during pregnancy can cause bleeding, cardiovascular stress, symptoms of anemia (such as fatigue, reduced physical and mental abilities, headaches, dizziness, and fatigue), prolonged hospitalization, decreased production of breast milk (ASI ) during childbirth, loss of iron reserves at postpartum and later on. ${ }^{3}$

Based on the profile of the West Sumatra Health Office in January to August 2016 the number of mothers with anemia was $23.8 \%$. While the prevalence of anemic pregnant women in the city of Padang was 9.3\%. According to data from the Padang City Health Office in 2016 the Puskesmas area with the highest percentage of anemia cases in pregnant women was $22.1 \%$ in Ambacang Health Center, $17.6 \%$ in Lubuk Buaya Health Center and $11.7 \%$ in Ikua Koto Health Center.

Iron has an important role in fetal growth. During pregnancy, iron intake must be added considering that during pregnancy the volume of blood in the mother's body increases, so that to be able to continue to meet maternal needs and supply food and oxygen to the fetus through the placenta, more iron intake is needed. The intake of iron is used by the fetus for its developing body, development of the brain and stored in the liver as a reserve until the baby is 6 months old. ${ }^{4}$

In agreement with with study in pregnancy, iron is needed for the first thousand days of life until the first two years of a child's life. If iron deficiency occurs, it can result in a permanent deficit and cannot return to normal and reduce productivity capacity. ${ }^{5}$

One of the effects on iron loss in infants is asphyxia, due to lack of iron function as an oxygen carrier. Neonatural asphyxia is a state of newborns who fail to breathe spontaneously and regularly immediately after birth accompanied by hypoxemia (low $\mathrm{O} 2$ pressure), hypercapnea (increased $\mathrm{CO} 2$ pressure) and end with acidosis. In general, asphyxia of newborns is a continuation of fetal asphyxia. Fetal assessment during pregnancy and childbirth plays an important role for infant safety. ${ }^{6}$ Poor maternal nutrition and chronic diseases such as anemia, hypertension, heart disease and others can result in fetal asphyxia, and will affect the fetus, which causes oxygenation disorders and lack of food substances associated with impaired placental function.

According to a report from the World Health Organization (WHO) about 23\% of all neonatal mortality rates worldwide are caused by neonatal asphyxia, with a greater proportion of stillbirths. An estimated 1 million children survive after experiencing asphyxia at birth with long-term morbidity such as cerebral palsy, mental retardation and learning disorders. ${ }^{4}$

The condition of neonatural asphyxia can be known by the APGAR score. APGAR score is a test used to assess the baby's asphyxia state. APGAR assessment uses five indicators consisting of heart rate, respiratory 
effort, muscle tone, reflex sensitivity and baby's skin color. ${ }^{7}$

In conclusion of the Laflame study in El Alto, Bolivia, highlights the fact that the application of hemoglobin adjustment for the diagnosis of anemia is very useful in predicting pregnancy outcomes. Using this adjustment method, pregnant women with anemia are strongly associated with the low APGAR value of infants at 1 and 5 minutes after birth, and shorter gestational length and higher parity. ${ }^{8}$

Based on the data above, the studyer wants to know the relationship between ferritin levels of pregnant women who have Fe deficiency anemia with ferritin levels and neonatal APGAR.

\section{METHODS}

This study was carried out from June 2017 to October 2017 in the working area of the Ambacang Health Center, Lubuk Buaya Health Center, Ikur Koto Health Center and Biomedical LaboratoryAndalas University Padang totalling 28 pregnant women who met the inclusion criteria. Blood sampling is done after the candidate respondent is given an explanation about background, purpose and benefits of the study and get written consent from the study subject.

Data processing is done by using editing, coding, entry and tabulatingmethod.Data analysis was performed using Shapiro-Wilk normality test. Analysis of the relationship between ferritin levels of pregnant women with iron deficiency anemia with neonatal ferritin levels was performed using Pearson test. To determine the relationship of ferritin levels and APGAR was performed using Mann Whitney test.

\section{RESULTS}

Table 1. Characteristics of Respondents

Characteristics Mean \pm SD

\begin{tabular}{lc}
\hline Mother Age (years) & $27.68 \pm 3.345$ \\
Pariity & $1.50 \pm 0.793$ \\
Gestational Age & $39.54 \pm$ \\
Maternal ferritin $(\mathrm{ng} / \mathrm{ml})$ & $6.65 \pm 1.936$ \\
Neonates ferritin $(\mathrm{ng} / \mathrm{ml})$ & $82.47 \pm 95.951$ \\
APGAR & $7.68 \pm 0.476$ \\
\hline
\end{tabular}

The results showed that the mean age of mothers was $27.68 \pm 3.345$ years, mean parity $1.50 \pm 0.793$ people, the mean gestational age of $39.54 \pm 1,105$ weeks, mean ferritin of mothers $6,65 \pm 1,936 \mathrm{ng} /$ $\mathrm{ml}$, mean ferritin of baby $82,47 \pm 95,951 \mathrm{ng} /$ $\mathrm{ml}$ and mean APGAR 7.68 $\pm 0,476$.

Relationship of Ferritin Levels of pregnant mother with Ferritin Levels neonate can be seen in the following figure:

Figure 1. Relationship of Mother Ferritin Levels with Neonatal Ferritin Levels

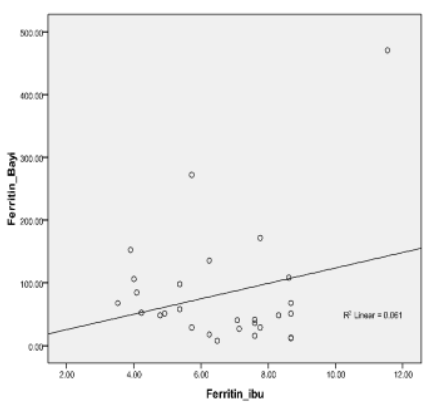

*correlation test Pearson

Table 2. The Relationship Between Ferritin Level Mother'sand APGAR

\begin{tabular}{lc|ccc}
\hline APGAR & $\mathbf{n}(\boldsymbol{\%})$ & & $\begin{array}{c}\text { Maternal } \\
\text { Ferritin } \\
\text { (ng / ml) } \\
\text { Mean } \pm \text { SD }\end{array}$ & $\begin{array}{c}\text { P } \\
\text { value }\end{array}$ \\
\cline { 1 - 2 } \cline { 5 - 6 } Asphyxia & $4(14.3)$ & & $7.52 \pm 1.337$ & 0.199 \\
No Asphyxia & $24(85.7)$ & & $6,50 \pm 2,003$ & $*$ \\
\hline
\end{tabular}

*Test Mann-Whitney

Table 2 shows that there is no significant relationship betweenmaternal ferritin levels with neonatal APGAR.

Table 3. Relationship Between Neonates Ferritin Level and APGAR

\begin{tabular}{cccc}
\hline Value & n (\%) & $\begin{array}{c}\text { Ferritin } \\
\text { Neonatal(ng / } \\
\text { ml) } \\
\text { Mean } \pm \text { SD }\end{array}$ & $\begin{array}{c}\mathbf{P} \\
\text { value }\end{array}$ \\
\hline Asphyxia & 4 & $12.37 \pm 4.144$ & 0.002 \\
\cline { 3 - 4 }
\end{tabular}




\begin{tabular}{lcc}
\hline \multicolumn{4}{c}{$(14.3)$} \\
Non & 24 & \\
Asphyxia $\quad(85.7)$ & & \\
* test Mann-Whitney \\
Table 3 shows a significant relationship \\
betweenlevels ferritin of neonataland \\
APGAR.
\end{tabular}

\section{DISCUSSION}

\section{Relationship ofMaternal ferritin levels with Neonatal Ferritin Level}

The subjects of this study consisted of 28 pregnant women who experienced $\mathrm{Fe}$ deficiency anemia in the work area of Ambacang Health Center, Lubuk Buaya Health Center and Ikur Koto Padang Health Center in June 2017 until October 2017.

Based on the results of the study, there is no significant relationship between ferritin maternalwith ferritin of neonates with $\mathrm{p}=$ 0.204 . Pearson correlation value is 0.248 which indicates the direction of a positive relationship means that the higher thelevel, ferritin maternalthe higher is thelevel ferritin neonatalwhere the strength with the strength of the relationship is weak. It was also found that the value of $r^{2}$ was linear $=0.061$ which means that $6.1 \%$ of neonatal ferritin levels were influenced by maternal ferriticity, while 93.9\% were influenced by other factors.

The same results were obtained by previous studies which found no relationship betweenserum ferritin maternalwithserum ferritin. umbilical cord where there is no difference in the iron content of children in the group of women with iron deficiency anemia or non-iron deficiency. ${ }^{9} 10$

Pregnancy is a condition that increases the mother's need for iron to meet fetal, placental needs and an increase in erythrocyte mass during pregnancy. Insufficient iron deposits before pregnancy and inadequate iron intake during pregnancy can lead to iron deficiency anemia in pregnancy. ${ }^{11}$

Iron plays a role in determining the intelligence of a child from intra uterine. Iron plays a role in neurocognitive and neurobehavioral development during the last two-thirds of pregnancy and the long-term consequences of iron deficiency in the perinatal period. Human and animal studies have shown that iron deficiency anemia that occurs since intra uterine is associated with the emergence of behavioral development disorders, nerve changes, which produce irreversible effects on the neurochemistry and neurobiology of the fetus. ${ }^{12}$

The basic principle of the biological process of iron in the fetus is that the use of iron in the body is prioritized for the formation of red blood cells compared to the need for other body tissues including the brain. Iron deficiency in the fetal brain will occur even though there is no anemia in the fetus if the need for iron exceeds the availability of iron in the body in pregnant women. ${ }^{13}$

Ferritin is currently considered the most important indicator in determining iron status in the iron deficiency stage where levels will decrease. However, it should be noted that ferritin will increase due to several factors including infection and inflammation, so that high values do not always show good iron status. Given the high prevalence of iron deficiency in pregnant women, the fetus and neonate are very at risk for iron deficiency. ${ }^{14}$ 15 Previous

Studies have had different results where the iron content of newborn umbilical cord blood is lower in mothers who have less iron content. The study found that there was a positive relationship between ferritin maternal serumlevels and iron reserves in neonates from mothers with advanced pregnancies with ferritin. lowIn addition, other studies also found that mothers with iron deficiency anemia could affect the iron reserves of newborns. ${ }^{16} 17$

Previous experimental studies have indeed shown that iron transfer across the placenta occurs in contrast to the surge in iron plasma concentration and transferrin saturation, but the mechanism that makes this action regulates maternal to fetal iron transfer is not completely clear. In experimental animals given high doses of iron do not give birth to a fetus who has 
excessive iron accumulation. In addition, there are other factors that can significantly influencelevels ferritin newbornsuch as the time of cord clamping and birth weight. ${ }^{9} 18$

\section{Relationship of Maternal Ferritin Levels with APGAR}

Based on the results of the study showed no association betweenlevels ferritin maternaland APGAR in pregnant women who experienced Fe deficiency anemia with $\mathrm{p}=0.199(\mathrm{p}>0.05)$.

Similar results were also found where there were no differences between the groups of women who were anemic and not anemic to the mean APGAR score in the first minute $(8.5 \pm 1.15$ vs. $8.3 \pm 1.3 \mathrm{~g} / \mathrm{dl} ; \mathrm{p}=0.15)$ and fifth $(9.7 \pm 0.72$ vs $9.6 \pm 0.69 ; \mathrm{p}=0.21) .{ }^{19}$

The APGAR score is a test used to assess infant asphyxia. APGAR assessment uses five indicators consisting of heart rate, respiratory effort, muscle tone, reflex sensitivity and baby's skin color. ${ }^{7}$

The presence of anemia during pregnancy and after pregnancy is the most common problem that occurs which has a significant effect on the baby and infant development. ${ }^{20}$ It has been reported that low hemoglobin levels increase the risk of low birth weight babies, preterm delivery and infants with SGA (Small for Gestational Age). Infants with SGA contribute a significant share of infant morbidity and mortality. 2021

Iron reserves in newborns can depend on maternal iron status. in many studies found that iron deficiency during pregnancy affects iron reserves in the fetus. One effect on reduced iron in infants is asphyxia where the assessment can be done using the APGAR score. Asphyxia is an important part that contributes to morbidity and mortality in infants. ${ }^{7}$

Different study results found a significant relationship between maternal hemoglobin and pregnancy outcomes, one of which is APGAR. Women with anemia had a 1.7-fold increased risk of their babies experiencing a low APGAR score in the first minute and a 2.2-fold increased risk of developing IUFD compared to non-anemic mothers. $^{22}$

The difference between this study and previous study is probably due to the different study methods and characteristics of the samples used by respondents. In addition, there are certain conditions that can cause neonatal asphyxia in addition to decreasing maternal iron levels.

Broadly speaking, there are two risk factors that can cause asphyxia neonatarum, namely perinatal and maternal risk factors. Low ferritin maternallevels are one of the risk factors included in maternal risk factors that can cause neonatal asphyxia. Other maternal factors suspected to be associated with asphyxia are maternal infections, multiple births and low socioeconomic status. The low level of paternal education, ethnicity, primipara, maternity facilities were also found to have a significant relationship with the occurrence of neonatal asphyxia. ${ }^{23}$

\section{Relationship of Neonatal Ferritin Levelswith APGAR}

Based on the results of the study showed there was a correlation betweenlevels ferritin neonataland APGAR in pregnant women who had Fe deficiency anemia with $\mathrm{p}=0.002(\mathrm{p}<0.05)$.

Nearly similar results were also found which assessed perinatal risk factors that could cause neonatal asphyxia. The study found that neonatal anemia had a significant relationship with the incidence of neonatal asphyxia (OR: 2.98; $\mathrm{p}=0.01$ ). ${ }^{24}$

Iron has an important role in fetal growth. During pregnancy, iron intake must be added considering that during pregnancy the volume of blood in the mother's body increases, so that to be able to continue to meet maternal needs and supply food and oxygen to the fetus through the placenta, more iron intake is needed. ${ }^{4}$

Anemia in pregnancy occurs because of low $\mathrm{Fe}$ reserves before pregnancy, inadequate nutritional intake with increasing needs. Fetal growth will deplete Fe reserves and increased $\mathrm{Fe}$ demand continues until the birth of the baby. ${ }^{25}$ 
One effect of reduced iron in infants is asphyxia where the assessment can be done using the APGAR score. This condition occurs due to lack of $\mathrm{Fe}$ function as an oxygen carrier. In general, asphyxia of newborns is a continuation of fetal asphyxia. Fetal assessment during pregnancy and childbirth plays an important role for infant safety. ${ }^{76}$

Iron is one of the constituents of hemoglobin. In conditions where iron deficiency occurs, hemoglobin does not form, which in turn will cause low hemoglobin levels in the body. This condition is called anemia due to iron deficiency. Low $\mathrm{Hb}$ levels in an anemic mother cause oxygen levels that are bound by red blood cells in the lungs and brought to the body's tissues to decrease. Hb levels and iron levels in cord blood and placental tissue have a linear relationship with maternal hemoglobin levels. Anemia in the mother has a significant relationship with anemia in newborns. A decrease in $\mathrm{Hb}$ levels will cause a decrease in oxygen levels in body tissues, then anaerobic metabolism will occur. This condition can cause the fetus to experience hypoxia and acidosis which can affect the APGAR value of the baby. ${ }^{26} 27$

Different study results found that there were no differences in APGAR scores in infants born to mothers with ferritin low or normal. The study also failed to find meaningful differences in terms ofassessments outcome other infantsuch as infant BMI (Body Mass Index), placental ratio and gestational age despite a significant decrease in infant body weight, crown-heel length, and placental weight from the lowest quartile to highestlevel ferritin maternal. ${ }^{18}$

The difference between this study and previous study is probably due to the different study methods and characteristics of the samples used by respondents. In addition, there are certain conditions that can cause neonatal asphyxia in addition to a decrease in the baby's iron content.

Broadly speaking, there are two risk factors that can cause asphyxia neonatarum, namely perinatal and maternal risk factors. Low ferritin babylevels are one of the risk factors included in perinatal risk factors that can cause neonatal asphyxia. Other perinatal factors are preterm birth, low birth weight ( $<2,500$ grams), cord twisting, and impaired biophysical profile. ${ }^{2428}$

\section{CONCLUSION}

Ferritin levels of pregnant women who had $\mathrm{Fe}$ deficiency anemia withneonatal ferritin levels have a positive correlation and are not statistically significant.

Ferritin levels of pregnant women with iron deficiency anemia with neonatal APGAR did not have a meaningful relationship. While ferritin levels of neonates and APGAR born by pregnant women who have Fe deficiency anemia have a significant relationship. 


\section{REFERENCE}

Ani, LS. (2013). Anemia Defisiensi besi : masa prahamil dan hamil. Jakarta : EGC.

Briawan, D. (2013). Anemia : masalah gizi pada remaja wanita. Jakarta : EGC

Breymann, C. Honegger, C. Holzgreve, W. Surbek, D. (2010). Diagnosis and Treatment of Iron-deficiency anaemia during pregnancy and postpartum. Arch Gynecology Obstetrics. vol. 282. pp. 577-580. doi:10.1007/s00404-010-1532-z

Kementerian Kesehatan RI. (2015). Profil Kesehatan Indonesia Tahun 2014. Jakarta : Kementerian Kesehatan RI.

Pontoh, S. Mayulu, N. Engka, JN. (2015). Hubungan Kadar Ferritin dan Asupan Protein Pada Ibu Hamil Trimester II-III di Kabupaten Bolaang Mongondow Utara. Jurnal e-Biomedik (eBm). vol. 3. no. 3. pp. 770-776.

Handini, PSN. (2010). Hubungan Anemia Gravidarum pada Kehamilan Aterm dengan Asfiksia Neonaturum di RSUD Dr. Moewardi Surakarta. Skripsi. Universitas Sebelas Maret. Surakarta.

Lissauer, T. Fanaroff, AA. (2009). At a Glance Neonatologi. (Alih Bahasa: Vidhia Umami). Jakarta : Erlangga

Laflamme, EM. (2010). Maternal Hemoglobin Concentration and Pregnancy Outcome : A Study of the Effects of Elevation in El Alto, Bolivia. MJM 2010 : 13 (1): 47-55.

Hussain, MAM. Gaafar, TH. Laulicht, M. Hoffbrand, AV. (1977). Relation of Maternal and Cord Blood Serum Ferritin. Archives of Disease in Childhood. vol. 52. pp. 782-784.

Paiva, A. Rondo, P. Pagliusi, R. Latorre, M. Cardoso, M. Gondim, S. (2007). Relationship between the iron status of pregnant women and their newborns. Rev Saude Publica. vol 41. no. 3 .

Wibowo N,Regina Purba RT. Anemia Defisiensi Besi dalam Kehamilan. Dexa Media, JanMaret 2006; 19(1).

Estrada Jose A, contreras Irazu, Rivero F Bernardo Pliego, Otero Gloria A. (2014) : Review Molecular mechanisms of cognitive impairment in iron deficiency: Alterations in brain derived neurotrophic factor and insulin like growth factor expression and function in the central nervous system, Nutritional Neuroscience, vol 17 no 5.

Lozoff Betsy, MD and Georgieff Michael K MD. (2006) : Iron deficiency and brain development, Seminar in Pediatric Neurology ; 13: 158-165

Knovich, M. A. (2009). Ferritin for the Clinician. National Institute of Health, 23 (5), 95-104.

Akhter, S. Momen, MA. Rahman, NC. Rahman SD, Karim, RE. Selim, S. Et al. (2014). Maternal Anemia and its Correlation with Iron status of Newborn. Birdem Medical Journal. vol. 4. no. 1

Shao, J. Lou, J. Rao, R. Georgieff, MK. Kaciroti, N. Felt, BT. et al. (2012). Maternal Serum Ferritin Concentration is Positively Associated withNewborn Iron Stores inWomen with Low Ferritin Status in Late Pregnancy. J. Nutr. vol 142. ed. 11.pp 2004-2009

Terefe, B. Birhanu,A. Nigussie, P. Tsegaye, A. (2015). Effect of Maternal IronDeficiency anemia on the Iron Store of Newborns in Ethiopia. Hindawi Publishing Corpotion Anemia. vol 2015. pp. 6 
Lao, TT; Tam KF; Chan, LY. (2010). Third trimester Iron Status and Pregnansy Outcomes in Non-ananemic Women; Pregnancy Unfavourably Affected by Maternal Iron Excess. Human Reproduction. Vol 15 no.8 pp.1843-48.

Dane, Banu; Arslan, Necmi; Batmaz, Gonca; and Dane, Cem. (2013). Does maternal anemia affect the newborn?Özgün Araştırma. pp.195-199.

Breymann C, Bian XM, Blanco-Capito LR, Chong C, Mahmud G, Rehman R. Expert recommendations for the diagnosis and treatment of iron-deficiency anemia during regnancy and the postpartum period in the Asia-Pacific region. Perinat Med 2011; 39: 113-121.

Ren A, Wang J, Ye RW, Li S, Liu JM, Li Z. Low first-trimester hemoglobin and low birth weight, preterm birth and small for gestational age newborns. Int $\mathbf{J}$ Gynaecol Obstet 2007; 98: 124-128.

Levy A, Fraser D, Katz M, Mazor M, Sheiner E. Maternal anemia during pregnancy is an independent risk factor for low birthweight and preterm delivery. Eur J Obstet Gynecol Reprod Biol 2005; 122: 182-186.

Francis, S. \& Nayak, S., 2013. Maternal Haemoglobin Level and Its Association with Pregnancy Outcome among Mothers. Nitter University Journal of Health Science, 3(3): 96-100.

Lee, ACC; Mullany, LC; Tielsch, JM; Katz, J; Khatry, SB; LeClerq, SC; et al. (2008). Risk Factors for Neonatal Mortality due to Birth Asphyxia in Southern Nepal. Pediatrics.vol. 121(5). pp.1381-90.

Nayeri, F; Shariat, M; Dalili, H; Adam, LB; Mehrjerdi, FZ; Shakeri, A. (2012). Perinatal risk factors for neonatal asphyxia in Vali-e-Asr hospital, Tehran-Iran. Iran J Reprod Med. Vol. 10. No.2. pp: 137-140.

Arisman. (2009). Gizi dalam daur kehidupan : buku ajar ilmu gizi (Edisi 2). Jakarta : EGC.

Al-Hilli, NM. (2010). The Effect of Maternal Anemia on Cord Blood Haemoglobin and Newborn Birth weight. Karbala Journal of Medicine. Vol. 2. No. 8-9.

Koura, GK; Ouedraogo, S; Le Port, A; Watier, L; Cottrell, G; Guerra, J; et al. (2012). Anaemia during pregnancy: impact on birth outcome and infanthaemoglobin level during the first 18 months of life. Tropical Medicine and International Health. volume 17 no 3 pp 283-291.

Lee, HS. Kim, MS. Kim, MH., Kim, YJ. Kim, WY. (2006). Iron status and its association with pregnancy outcome in Korean pregnant women. European Journal of Clinical Nutrition. vol. 60. pp.1130-1135 


\section{BIOGRAPHY}

1. Zuliyana was born at Sungai Pakning in August 1988, completed midwifery education for 3 years at the STIKes Payung Negeri Pekanbaru in 2009. Zuliyana earned her Bachelor's degree from department of D4 Midwifery, STIKes Al-Insyirah Pekanbaru in 2011 and later her master's degree in Program of Magister Midwifery, Faculty of Medicine, Andalas University padang in 2018. Currently she is a lecture at Akademi Kebidanan Salma.

2. Prof. DR. dr. Yanwirasti, PA (K) was born in September 1947. Later her Doctor's Degree in Program of Doctor, Faculty of Medicine, Airlangga University Surabaya. Currently she is Professor and lecture by Department of Anatomical Pathology, Faculty of medicine at Andalas University Padang and she can be reached through: yanwirasti@yahoo.com.

3. dr. Roza Sri Yanti, SpOG (K) was born in February 1974. Currently she is a lecture at Program of Magister Midwifery, Faculty of Medicine, Andalas University padang and worked as an obstetrics and gynecology specialist at Sub Division Feto Maternal, RSUP DR. M. Djamil Padang. 